\title{
Consumption habits and economic impact of Liebherr 2019 ITTF World Table Tennis Championships
}

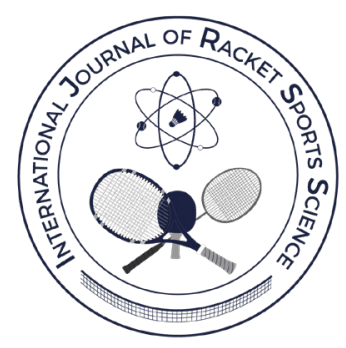

Tamás Laczkó ${ }^{(1}$ 1; Pongrác Ács ${ }^{\circledR}{ }^{1}$; Miklós Stocker $^{\left({ }^{2}\right.}$; Dávid Paár ${ }^{\oplus_{1}}$

1 University of Pécs, Faculty of Health Sciences, Pécs, Hungary

2 Corvinus University of Budapest, Institute of Business Economics, Budapest, Hungary

Received: $19-06-2020$

Accepted: 21-12-2020

\begin{abstract}
Organising international sports events became one of the most important elements of the prioritized sports sector in Hungary. The main goal of this study was to examine the economic impact of Liebherr 2019 ITTF World Table Tennis Championships (WTTC) for the Hungarian GDP. The impact is based on consumption habits of stakeholders and total budget of organisers so it was necessary to analyse the characteristics of passive sports tourists and all other stakeholders and their spending too. Consumption of stakeholders were surveyed with questionnaire $(n=1097)$ and the budget of the organisers were presented by the Hungarian Table Tennis Association. We have used the secondary data of Hungarian Statistical Office and Eurostat for input-output modelling. Expenditures and spending behaviour of stakeholders were calculated by inferential statistics, differences were tested by independent-samples T tests, ANOVA and Chi-square tests. Input-output modelling method was used for estimating the direct and indirect macroeconomic impacts. Daily spending of domestic (47.9 EUR/day) and foreign (102.8 EUR/day) passive sports tourists coming to the WTTC were calculated. Foreign passive sports tourists spent an average 3.85 days in the country. Examining the macroeconomic effects it can be stated that every EUR of government support increased the country's GDP by 1.21 EUR and generated a tax of 1.01 EUR in 2019. Expenditures of spectators and participants contributed $24 \%$ of the generated GDP. Passive sports tourists of WTTC spent more money than the general domestic and foreign tourists (20.6 EUR/day and 51.8 EUR/day respectively) or even the domestic or foreign sports tourists (24.7 EUR/day and 54.7 EUR/day respectively). They spent more time than general foreign tourists or foreign sports tourists as well (2.26 days and 2.29 days respectively) in Hungary. The Hungarian government provided almost 4 million euros support to the organisers and this amount is exceeded by the total contribution of WTTC to the Hungarian GDP (4.7 million EUR).
\end{abstract}

Keywords: World Table Tennis Championships, consumption habits, economic impact, input-output model

Correspondence author: Tamás Laczkó, joola.hu@gmail.com

Cite this article as:

Laczkó, T., Ács, P., Stocker, M., Paár D. (2020). Consumption habits and economic impact of Liebherr 2019 ITTF World Table Tennis Championships. International Journal of Racket Sports Science, 2(2), 37-46.

This is an open access article under the CC BY license (http://creativecommons.org/licenses/by/4.0/). 


\section{INTRODUCTION}

Tourism areas for sports and physical activity have been constantly growing since the turn of the millennium. Tourism and economic professionals predict a dynamic expansion in active and passive sports tourism for the next decade (Dreyer, 2002; Bánhidi, 2015; Borbély \& Müller, 2015). Sports events tourism is one of the highlights of sports tourism and it has been growing significantly in recent decades. Sports events and especially international sports events are nowadays characterized by fast paced evolution. Organisers focus on intangible values i.e. experience and entertainment (sometimes even at the expense on sport's professional aspects), which generate the emergence of new competition series and forms (e.g. new multisport events such as the European Games or the new World Table Tennis Series). At the same time, the number of viewers of worldwide sports events and the amount of its revenues are growing, and we can clearly see the trend of globalisation regarding the international sports events (Stocker, 2013; Bánhidi, 2018; Laflin, 2018; Laczkó \& Stocker, 2020).

One of the characteristics of sports events tourism is that they have two main target groups that differ in their motivation and characteristics. The first is the participants' group (such as athletes, delegates, organisers, etc.) whose travels are classified as professional tourism based on their characteristics and motivations, while the second is the spectators' group (local, domestic and foreign spectators) whose touristic consumption is interpreted as a part of leisure tourism (Standeven \& De Knopp, 1999; Lasztovicza \& Béki, 2016). The size of the global spectators' market and its rapid expansion have placed the study of spectators' characteristics and consumption habits into the focus of international sports and economics researches (Bánhidi, 2018). Based on this research, it can be said that nowadays spectators attend sports events primarily to gain experiences and let themselves to be entertained, therefore, they are looking for non-sports related attractions and services, and can be characterized by increased demands for these attractions compared to the average tourist (Albers, 2004; Chen \& Funk, 2010; Stocker \& Laczkó, 2020).

Although the main focus of the Hungarian tourism is not sports tourism, it can be said that more and more attention has been paid to the development of sports-related tourism trends in recent years (Sulyok \& Magyar, 2014; Hungarian Tourist Agency, 2017). The expansion in the sector is explained and supported by several social and economic trends as well as government decisions. Among the social trends, the rising participation rate of the Hungarian population in recreational sports for health purposes and the increasing sports consumption must be highlighted (Kovács, Paár, Elbert, Welker, Stocker, \& Ács, 2015; European Commission, 2018). An important driver of the development of Hungarian sports tourism is the government's decision to handle sport as a strategic sector since 2010, as well as the fact that the area also appears as a priority in tourism development strategies at various levels. Organising international sports events became one of the most important elements of the prioritised sports sector (Stocker \& Szabó, 2017) and its over-spilling effects are in focus of scientific researches nowadays (Laczkó \& Paár, 2018; Paár \& Laczkó, 2018). As a result the number of international sports events applied for and held in the country increased significantly from 2010 and also included events with higher prestige and professional quality. More than 120 international sports competitions were held in Hungary in 2019. The Formula One race, the World Table Tennis Championships (WTTC), the Canoe Sprint World Championships, the Fencing World Championships and the Modern Pentathlon World Championships were held among others this year. According to the data of Sportcal Global Communications, Budapest was the 3rd, while Hungary was the 18th in the world ranking of settlements and countries organising international sports events in 2019 (Sportcal Global Communications, 2019a).

Hungary has a very successful past in the sport of table tennis and the Hungarian Table Tennis Association has considerable experience in organising international sports competitions. Hungary is the second most successful table tennis nation with 202 medals at the World Table Tennis Championships. These results came from a series of successes between the two world wars and the 1950s and 1970s. Hungary has paid special attention to the application and organisation of international table tennis competitions in the recent years. In addition to the annual World Tour series in the country, the European Championships (EC) was held in 2016, while the individual WTTC was held in April 2019 and the European Veteran Championships (EVC) was held one month later. Budapest hosted the WTTC for the fourth time in its history in 2019 (after 1929, 1931 and 1950). Budapest is the second placed settlement in the world after London regarding the number of organised World Table Tennis Championships. Budapest wanted to become the centre of international table tennis life with these events in 2019.

The main research question of this paper is the economic impact of the Liebherr 2019 ITTF World Table Tennis Championships. This total impact can only be calculated including the consumer habits of different stakeholders of the event, therefore the consumer habits will be demonstrated first, then the economic impact calculations will come.

The hypothesis of the study is that the Liebherr 2019 ITTF World Table Tennis Championships contributed more to the Gross Domestic Product of Hungary than the subsidy it got from the government. 


\section{MATERIALS AND METHODOLOGY}

Information about the consumer behaviour of spectators and participants was obtained by the survey methodology and information about the budget of the event was provided by the local organising committee.

\section{Design \& Procedures}

We created slightly different questionnaires for different stakeholder groups in international sports events to obtain primary research data, and we selected the sample with quota sampling. Interviewers were sent to the event and they recorded the answers of the spectators. The questionnaires were created with different types of questions: open-ended questions (some financial and some textual), closedended questions and Likert-scale questions about the basic statistical data of the respondents, the different types of expenditures spent and their amounts, the length of stay, the different tourist appeals, the quality of the event organisation, the willingness to return to the country and the attitude about how spectators rated Hungarian people's hospitality.

Further primary research data was provided by the local organising committee about the budget of the events and the numbers of different participants. According to secondary sources, we used public data from the national sports associations, the Hungarian Central Statistical Office (HCSO), the Statistical Office of the European Union (Eurostat) and other sports professional fora. The gathered primary and secondary data were used as inputs for the inputoutput modelling.

Expenditures and spending behaviour of spectators, travel and other tourist behaviour were calculated by the primary data with inferential statistics.

The differences of the given variables were calculated with independent-sample $T$ tests, ANOVA tests and Chi-square tests depending on the operationalization of the given variable. The significance level was set at $p<0.05$ (Ács, 2007; Ács, 2014).

\section{Participants}

Our interviewers recorded 1139 survey entries from the spectators' and the participants' questionnaires together at the Liebherr 2019 ITTF World Table Tennis Championships. We had to exclude 42 entries because of interviewer data entry problems or because of the unfinished status of the questionnaires. The final sample consists of $n=1,097$ survey entries from which $\mathrm{n}=355$ are from domestic spectators, $\mathrm{n}=641$ are from foreign spectators and $n=281$ are from professionals (athletes and sports professionals) as it can be seen in table 1. Altogether $n=1,097$ person was included in the sample from the participating 11.5 thousand which means $9.5 \%$ sample rate.
Table 1.

Sample sizes and number of participants at Liebherr 2019 ITTF World Table Tennis Championships (Budapest, HU)

\begin{tabular}{lcccc}
\hline & $\begin{array}{c}\text { Domestic } \\
\text { spectators }\end{array}$ & $\begin{array}{c}\text { Foreign } \\
\text { spectators }\end{array}$ & Professionals & Total \\
\hline Sample size (n) & 355 & 461 & 281 & 1,097 \\
Participants (N) & 5,577 & 3,810 & 2,199 & 11,586 \\
Proportion (\%) & $6.4 \%$ & $12.1 \%$ & $12.8 \%$ & $9.5 \%$ \\
\hline
\end{tabular}

Sources: Authors' compilation

\section{Analysis}

The direct and indirect impacts of the World Championships were calculated by the economic input-output modelling method, which is widely used by impact calculation studies in event tourism (European Commission, 2012; Kóródi, 2011; Kundi, 2012; KPMG, 2015; Laczkó-Stocker, 2018; Stocker-Laczkó, 2020).

Economic impact is mostly connected to the organisation of the event and the consumption of the participants as the consumption of the spectators is usually responsible for a smaller amount in table tennis.

The economic impact of the international sports event was calculated from the direct expenditure of the event and its participants and the indirect impact they caused in the national economy. From the spectators' expenditure the expenditure of entry tickets was ignored as these were included in the budget of organisers. Travel costs of foreign spectators were also excluded as these occur usually in their home country which means it does not have impact in the Hungarian economy. Those spectators' expenditures were excluded from the impact analysis who reported that their primary travel reason was different than the World Championships, as their economic impact should have been calculated in the impact analysis of the primary reason of travel. According to Hungarian spectators related calculations in the impact analysis we decreased the number of Hungarian spectators with $1.7 \%$ as their primary motivation was not the WTTC and we also decreased the expenditures of the remaining Hungarian spectators by $16.7 \%$ as they would have been spent money in Hungary if the WTTC would not take place in the country. Exact measures are the benchmarks taken from another Olympic sport's World Championships in Hungary in 2019.

Financial contribution of sponsors was included in the budget of the organisers. Non-financial sponsorships were included in the research too. These were products, services and sporting goods. Sponsors also contributed to the event with letting their employees work in the event, their fair value was also included in the research.

As the organisation of the event also included imported goods but these imported goods created value for their home economy, therefore they were excluded from the calculations. 
The created input-output model used the previously described data. We used multipliers obtained from the input-output analysis of Hungarian sectors to estimate the indirect impact as well (Stocker \& Boda, 2018). The different expenditures spent in accordance with the World Championships were spent in the following sectors: sports activities and amusement and recreation activities; accommodation and food service activities; transportation and storage; manufacture of food products, beverages; manufacture of wearing apparel; human health activities; services to buildings and landscape activities; and education. Sectoral multipliers were used for the expenditure to the respective sectors and we could estimate the impact of foreign spectators' expenditures on the Hungarian GDP with these calculated multiplier effects.

All statistical calculations were made by IBM SPSS Statistics 25 and Microsoft Excel (from Microsoft Office 365 Proplus).

\section{RESULTS}

\section{Consumption and touristic characteristics of the WTTC}

The characteristics and opinions of domestic spectators are based on a sample of 355 people, which is $6.4 \%$ of the Hungarian spectators.

A total of $75.2 \%$ of Hungarian spectators were men, $24.8 \%$ were women at the WTTC in 2019. In terms of age distribution $22.0 \%$ were under 20 years of age, $14.4 \%$ were $20-29$ years of age, $10.7 \%$ were $30-39$ years of age, $24.8 \%$ were $40-49$ years of age, $16.1 \%$ were $51-60$ years of age and $12.0 \%$ were over 60 years.

A total of $30.7 \%$ of the respondents came from Budapest to the competition. $18.5 \%$ of domestic spectators travelled for up to 1 hour and a further $25.1 \%$ travelled between 1 and 2 hours to watch the competition in addition to the this. $25.7 \%$ of the domestic spectators came from a distance of more than 2 hours. It can be said that more than half of the domestic spectators (50.8\%) travelled at least 1 hour to watch the competition. Domestic spectators came to the WTTC from all counties of the country.

According to modes of travel $71.2 \%$ of the spectators arrived by car (or minibus), $18.6 \%$ by public transport, $8.8 \%$ by train/coach, and $1.4 \%$ used other vehicles (such as bicycles etc.).

More than a third of the respondents (33.8\%) watched the competition with their families, $22.1 \%$ of them came alone, $19.8 \%$ came with friends and acquaintances, while $24.3 \%$ came with sports mates.

The Hungarian spectators watched an average of $2.56(\mathrm{SD}=2.15)$ competition days.

According to accommodation $20.0 \%$ of the spectators booked accommodation related to the competition and they spent an average of 3.18 (SD = 2.56) nights. Taking all domestic viewers into account, they spent an average of $0.64(S D=1.71)$ guest nights in and around Budapest. This meant a total of 3,569 guest nights in the capital during the competition period. Most of the used accommodations were cheaper ones, such as sleeping with friends or lowerrated commercial accommodations. Only $38.0 \%$ of those who spent guest nights related to the event slept in 3-stars or higher rated hotels (12.7\% in 4-stars hotels and $25.3 \%$ in 3 -stars hotels), while $40.1 \%$ of them slept by friends and acquaintances and $19.7 \%$ of them spent their nights in rented apartments or other non-commercial accommodation.

Figure 1 shows the distribution of Hungarian spectators' expenditure. Domestic spectators spent an average of 47.9 EUR (SD = 49.5) per day of the competition. This amount is significantly higher than the average 20.6 EUR $(t=10.4, p=0.000)$ daily spending by the average Hungarian tourists on multi-day trips in Hungary in 2019 and the average spending of 24.7 EUR on cultural and sports events $(t=8.8, p=0.000)$ (HCSO, 2020).

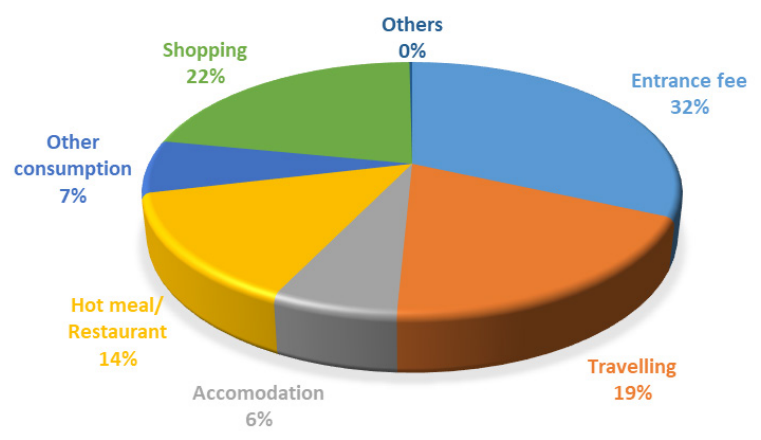

Figure 1. Distribution of Hungarian Spectators' Expenditure (\%)

Domestic spectators rated the entertainment value of the competition as good, as $62.5 \%$ of the respondents rated the WTTC as five on a scale of 1 to 5 . The mean of the ratings was $4.48(S D=0.87)$. Only $5.9 \%$ of the respondents rated the entertainment value of the competition as 3 or lower. The followings were considered important among the entertaining elements of the competition: the players' playing level, the quality of the matches $(4.71, S D=0.07)$, the information announcements $(4.44, \mathrm{SD}=0.09)$, the work of the organising staff $(4.41, \mathrm{SD}=0.09)$ and the presence of domestic players $(4.26, \mathrm{SD}=0.1)$. The presence of show elements $(3.46, \mathrm{SD}=0.14)$ and the competition's unpredictability factor $(3.89, \mathrm{SD}=0.15)$ were considered significantly less important.

The quality of the competition's organisation was rated as slightly weaker, averaging 4.30 (SD = 1.11).

The characteristics and the opinions of the foreign spectators are based on a sample of 461 people, which is $12.1 \%$ of the foreign spectators.

A total of $75.1 \%$ of foreign spectators were men and $24.9 \%$ were women. In terms of age distribution $8.1 \%$ were under 20 years of age, $26.5 \%$ were $20-29$ years of age, $21.0 \%$ were $30-39$ years of age, $22.1 \%$ were $40-49$ 
years of age, $13.8 \%$ were $51-60$ years of age and $8.5 \%$ were over 60 years (see Figure 2).

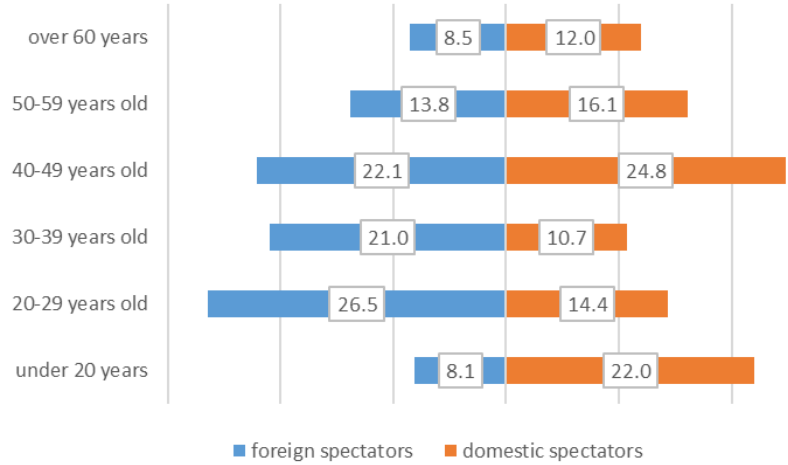

Figure 2. Age Distribution of Domestic and Foreign Spectators at the WTTC

The sample included citizens of 34 countries. 14.1\% of respondents came from Asia (China, Japan, India, Kazakhstan, Lebanon, Philippines), 0.4\% came from the Americas (USA, Brazil) while the vast majority came from European countries (85.5\%). Most Europeans came from Germany (24.7\%), Slovakia (17.1\%), Romania (6.1\%), Sweden (5.4\%) and England (4.3\%).

More than a third (34.7\%) of foreign spectators arrived by road by their own car (or minibus) and a significant number of them also arrived by plane (45.4\%) to Hungary. Due to the favourable geographical location of Budapest, a significant number of foreign spectators also arrived by train (19.2\%).

The foreign spectators of the WTTC spent an average of 3.85 nights $(S D=2.08)$ in Hungary. 53.7\% of them spent their nights in at least 3-stars hotels (38.4\% in 4 - and 5 -stars hotels), while $35.4 \%$ slept in rented apartments. Foreign spectators spent a total of 13,488 nights related to the WTTC.

Foreign spectators spent an average of 102.8 EUR $(S D=64.3)$ per day without travel costs during the competition, while this amount was 128.2 EUR (SD $=95.2)$ per day if travel costs were included. This meant an average of 624 EUR $(S D=645)$ including travel costs for the entire stay in Budapest. The daily spending of foreign spectators of the WTTC was significantly higher than the general foreign tourists' 51.8 EUR/day $(t=17.0, p=0.000)$ and the average spending of tourists arriving especially at sports events which was 54.7 EUR/day ( $t=16.0 ; p=0.000)$ in Hungary in 2019 (HCSO, 2020). Distribution of foreign spectators' expenditure can be seen in Figure 3.

Foreign spectators rated the quality of the WTTC as favourable, as more than four-fifths ( $85.1 \%)$ of the respondents rated the organisation of the competition as at least four. $11.4 \%$, of them rated it as three, and only a very small number (3.5\%) gave a less favourable rating. The average rating of the foreign spectators was $4.26(S D=0.80)$.

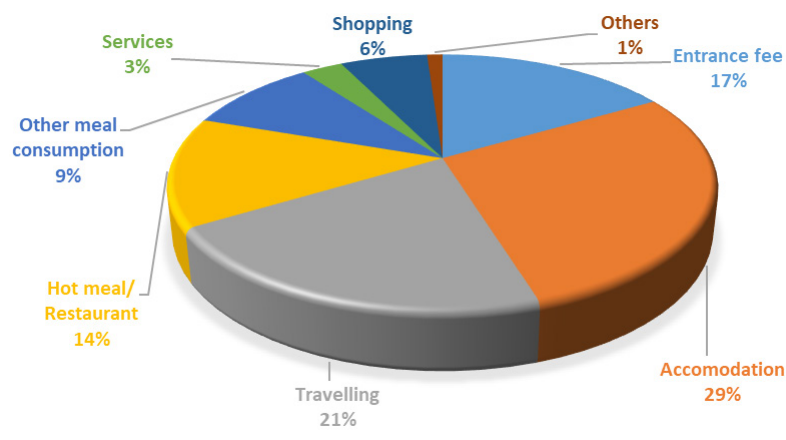

Figure 3. Distribution of foreign spectators' expenditure (\%)

Examining the tourism related consumption of foreign spectators, it can be said that almost two thirds of the respondents $(61.0 \%)$ were curious about the tourist attractions of Budapest and its surroundings. Several tourist destinations were visited by $37.2 \%$ of foreign spectators on several occasions in addition to the WTTC. Foreign spectators viewed mostly the main tourist attractions of Budapest similarly like general tourists. The city centre (Parliament, Danube riverbank) and the UNESCO World Heritage's sites (Buda Castle, Heroes' Square, Andrassy Street) were visited by $88.3 \%$ of the foreign spectators, while $10 \%$ of foreign spectators were looking for entertainment opportunities, but cultural (1\%) and shopping tourism $(0.4 \%)$ motives were negligible. Only $2 \%$ of spectators were involved in programs organised by tourism providers.

Foreigners rated the hospitality of Hungarians averagely at $4.6(\mathrm{SD}=0.61)$ based on the experiences of their trip to Hungary related to the WTTC.

The vast majority of foreign spectators would like to return into Hungary in the future. More than half of them (57.7\%) would like to return within 5 years based on their previous experiences, while the proportion of those who refuse to return is only $3.5 \%$.

There is a significant relationship between the perception of hospitality and the willingness to return $\left(\chi^{2}=37.19 ; p=0.000\right)$. It can be said that those who rated hospitality more positively plan to return to Budapest in the future (64\% of those who rated hospitality as 5 plan to return to Budapest within 5 years).

The willingness to return was also significantly influenced by the assessment of the organisation of the competition $\left(\chi^{2}=28.9 ; p=0.004\right)$. Those who considered the quality of the organisation to be more favourable would return to the Hungarian capital in a larger proportion in the future. Almost two-thirds (63.4\%) of the foreign spectators who rated the organisation as the best possible (as 5 ) would like to return in the next 5 years.

The characteristics and the opinions of the professional participants are based on a sample of 281 people, which is $12.8 \%$ of the professional participants. 
Foreign participants came to Budapest from 99 countries of all five continents. The foreign participants spent an average of $6.0(S D=2.1)$ and a total of 13,003 guest nights in the event's 9 official hotels (two 3-stars, five 4-stars and one 5-stars) in Budapest.

$82 \%$ of the participants arrived into the Hungarian capital by plane, while $16 \%$ arrived by road (car, minibus).

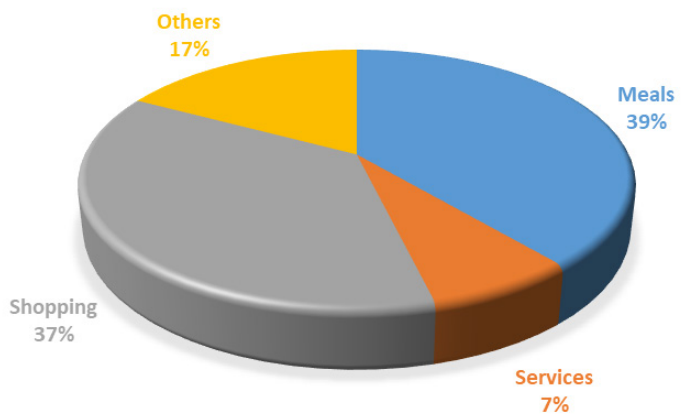

Figure 4. Distribution of the participants' local expenditure (\%)

The hospitality of the participants (in terms of accommodation, meals and transfers) was part of the accreditation, so we wanted to know more about their additional expenses. The participants spent an average of 265.3 EUR (SD = 386.1) during their stay in Budapest, which was 44.9 EUR (SD = 65.3) per day in addition to their basic hospitality. Players spent significantly the least (29.2 EUR/day; SD = 37.7), while other participants (ITTF members, media professionals, umpires and referees, technical staff) spent the most (61.6 EUR/day; $\mathrm{SD}=87.4$ ) among participants (coaches and delegates spent 44.1 EUR/day; SD = 39.1) $(p=0.034)$. The overall structure of their spending is shown by Figure 4.

The quality of organisation was rated averagely $4.24(S D=0.85)$ by the participants.

A total of $47 \%$ of the participants visited the city centre because of non-competitive motivations in addition to their duties related to the sports event. The range of tourist attractions visited was almost exclusively concentrated in the downtown and World Heritage sites (96.9\%), only $2 \%$ visited spas and other activities.

The hospitality of the Hungarians was judged by the participants very favourably similarly to the foreign spectators, averaging 4.6 (SD = 0.69). The willingness to return among the participants was also reported very similarly as by the spectators (although probably with different goals) at the same time, $55 \%$ of foreign participants plan to return to Budapest within 5 years, while only $2.6 \%$ do not want to come to Hungary again.

\section{Economic impact analysis of the 2019 World Table} Tennis Championships

Direct expenditure related to the 2019 World Table Tennis Championships was 7.15 EUR million as it can be seen in table 2.

Table 2.

Net direct expenditure by stakeholders in LIEBHERR 2019 WTTC (EUR)

\begin{tabular}{llllll}
\hline Organisers & Sponsors & $\begin{array}{l}\text { Extra ex- } \\
\text { penditure of } \\
\text { Participants }\end{array}$ & $\begin{array}{l}\text { Foreign } \\
\text { spectators }\end{array}$ & $\begin{array}{l}\text { Domestic } \\
\text { spectators }\end{array}$ & Total \\
\hline $5,106,235$ & 59,090 & 461,854 EUR & $\begin{array}{l}1,259,134 \\
\text { EUR }\end{array}$ & $\begin{array}{l}264,742 \\
\text { EUR }\end{array}$ & $\begin{array}{l}7,151,055 \\
\text { EUR }\end{array}$ \\
\hline
\end{tabular}

Source: Authors' compilation

Direct revenue to the central budget from the WTTC was 2.32 million EUR, which consists of VAT, employee related taxes and insurance. Local government will get tourist tax and local business tax and indirect tax revenues which are also created by the multiplying effect of the demand of WTTC.

Average import ratio of the segments from where the WTTC procured products and services is $4 \%$, therefore the demand side of the organisation and the other stakeholders expenditure had to be decreased by this amount in the economic impact analysis. Estimated import of the event was 294 thousand EUR, therefore direct national impact of WTTC was 6.86 million EUR.

For the suppliers be able to deliver products and services indirect products and services were needed, therefore the given segments' economic multiplier effect had to be taken into account. According to the structure of the expenditure the weighted average multiplier became 1.71, which means that the 7.15 million EUR demand of the WTTC needed 11.75 million EUR output from the Hungarian supply chain, which means the WTTC generated 11.75 million EUR output in the Hungarian economy.

The weighted average added value multiplier of the segments of the expenditure structure of WTTC is 0.36 , which means that WTTC generated 4.28 million EUR added value in the Hungarian economy.

Other taxes can be also calculated from inputoutput analysis, the weighted average multiplier of the respective economic segments was 0.04 , which means other taxes generated by WTTC were 502 thousand EUR. WTTC created 4.78 million EUR GDP contribution altogether.

Income taxes and social security paid to the central budget from the generated GDP of WTTC was 1.12 million EUR on top of what 2.9 million EUR VAT was also paid into the budget. 


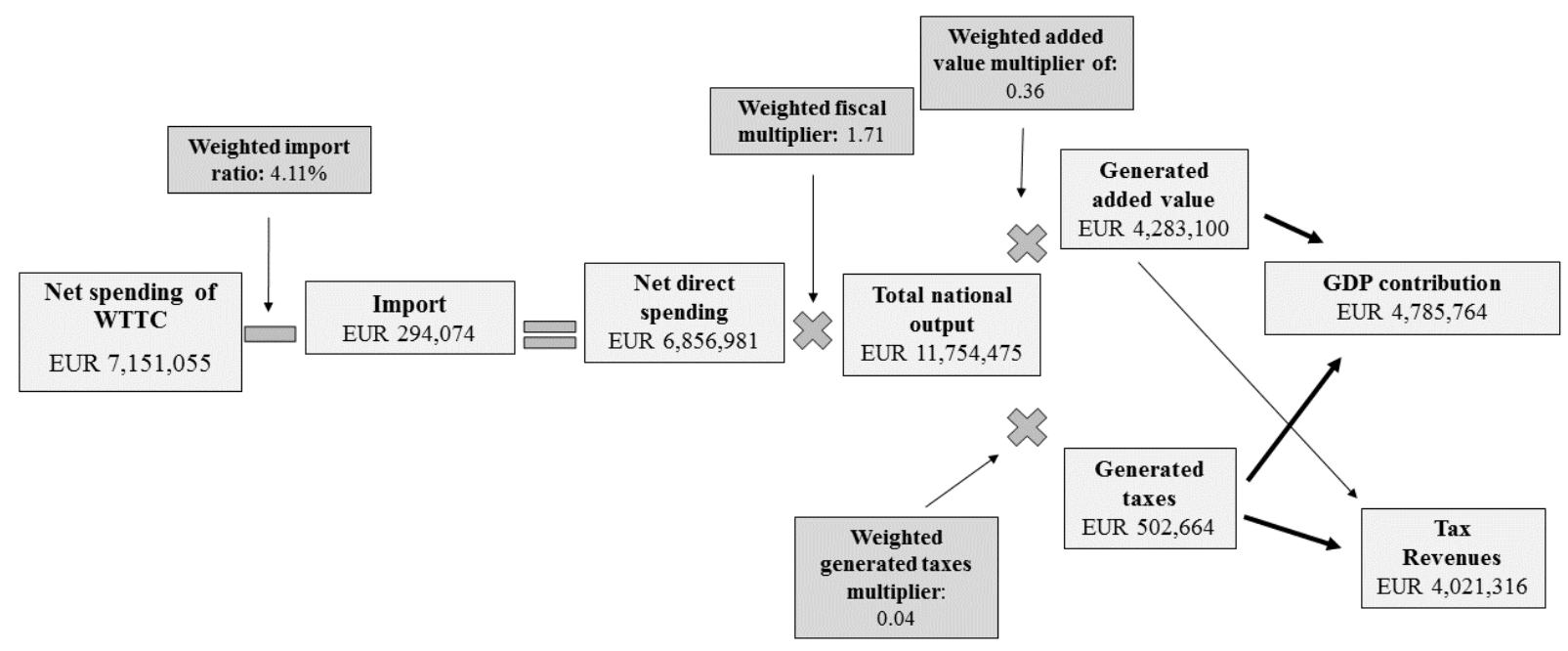

Figure 5. Economic impact of Liebherr 2019 WTTC

Gross financial subsidy of the Hungarian government was 3.95 million EUR. The hypothesis of the study was verified, the Liebherr 2019 ITTF World Table Tennis Championships contributed more to the Gross Domestic Product of Hungary (4.78 million EUR) than the subsidy it has got from the government. Even the tax revenues the Hungarian Central Budget realized related to event were higher (4.02 million EUR) than the subsidies.

\section{DISCUSSION}

Laczkó and Stocker (2018) calculated economic impact of international racket sports events organised in Hungary with which the WTTC can be compared with as it can be seen in table 3 .

Table 3.

Economic impact per participant of international sports events in racket sports in Hungary

\begin{tabular}{lcccc}
\hline $\begin{array}{c}\text { Impact per } \\
\text { participant } \\
\text { (person) }\end{array}$ & $\begin{array}{c}\text { Net } \\
\text { spending }\end{array}$ & $\begin{array}{c}\text { Total } \\
\text { National } \\
\text { Output }\end{array}$ & $\begin{array}{c}\text { GDP } \\
\text { contribution }\end{array}$ & $\begin{array}{c}\text { Tax } \\
\text { revenues }\end{array}$ \\
\hline $\begin{array}{l}\text { LIEBHERR 2019 } \\
\text { ITTF World } \\
\text { Championship }\end{array}$ & 617 EUR & 1,015 EUR & 413 EUR & 347 EUR \\
$\begin{array}{l}\text { Table Tennis } \\
\text { World Tour 2017 }\end{array}$ & 233 EUR & 374 EUR & 158 EUR & 102 EUR \\
$\begin{array}{l}\text { Table Tennis } \\
\text { U13 Hungarian }\end{array}$ & 307 EUR & 490 EUR & 203 EUR & 133 EUR \\
Open 2017 & & & & \\
$\begin{array}{l}\text { Badminton } \\
\text { U18 Hungarian }\end{array}$ & 265 EUR & 437 EUR & 184 EUR & 132 EUR \\
Open 2017 & & & & \\
\hline
\end{tabular}

Source: Authors' compilation based on Laczkó \& Stocker (2018) p. 72

The different sizes of the events are clearly shown in the table, but average spending and contribution also vary. Net spending per participant was 617 EUR in WTTC whereas 233 EUR in World Tour, 307 EUR in U13 Hungarian Open and 307 EUR in Badminton U18 Hungarian Open. This shows that those who came to the Table Tennis World Championships were willing to spend significantly more than those who came to smaller international events. This is supporting expectations however as if someone comes to a major event then he/she is willing to pay more. We can also understand that the spending in U13 Hungarian Open was higher than in the other two remaining events as with young children parents also travel, who are eager to spend more. Tax revenues per participant is very interesting as these averages shows that at least how much money is a participant worth in government subsidy. As in most cases significant immaterial value is created besides the economic value (Stocker, 2013), therefore if an event's tax contribution can break even on the government subsidy all immaterial value would be a net benefit. WTTC contributed 347 EUR per participant tax revenues to the Hungarian Central Budget, whereas World Tour contributed 102 EUR, U13 Hungarian Open 133 EUR and Badminton U18 Hungarian Open 132 EUR per participant.

According to empirical results domestic spectators are elemental in international sports events organised in the European Union as their proportion is from $70 \%$ to $99 \%$ of all spectators depending on the given sports (Schwark, 2005; Sportcal Global Communications, 2017; Laflin, 2018; Sportcal Global Communications, 2019a; Sportcal Global Communications, 2019b). However the proportion of domestic spectators was only $59 \%$ is at WTTC. This difference is due to the favourable geographic and economic situation of Hungary in this aspect, namely that Budapest is very easy to reach from other European countries with around 1-2 hour flight. The purchasing power of most European spectators are very strong if they spend in Hungary. These make a world championship in Budapest easy to reach and affordable. 
According to Sportcal Global Communications (2018) the daily spectator expenditure was 116.8 EUR in the World Games 2017 which was organised in Wroclaw. The average total expenditure was 138 EUR per spectator at the IFF Men's World Floorball Championships 2018 in Prague which was 37.5 EUR per day for domestic (Czech) spectators and 96.25 EUR per foreign visitors. In contrast daily expenditure of foreign visitors was 128.2 EUR and 624 EUR for the entire stay while 47.9 EUR per day and 122.6 EUR for the entire competition at WTTC (Sportcal Global Communications, 2017; Sportcal Global Communications, 2019b).

The organisation of the competition was rated on average 4.27 by all respondents $(S D=0.92)$, which can be considered a favourable rating mainly in view of the fact that $86.6 \%$ of the respondents rated the event as 4 or 5 . However if we compare the participants (mean $=4.24 ; \mathrm{SD}=0.85$ ), the foreign spectators (mean $=4.26$; $\mathrm{SD}=0.80$ ) and the Hungarian spectators (mean $=4.30$; $S D=1.11)$, it can be stated that Hungarian spectators rated the organisation significantly better than foreign spectators and participants $\left(\chi^{2}=10.648 ; p=0.005\right)$.

The proportion of foreigners was high (41\%) among the spectators, which may be explained by Hungary's favourable transport and geographical situation, relative low prices, the popularity of Budapest among Chinese tourists and the fact that an event of similar importance has not been held in the CEE region for more than a decade.

The groups participating in the WTTC spent a total of more than 30,000 guest nights (30,060 nights) in Budapest, of which $71.8 \%$ were spent in a hotel with at least a three-stars rating.

It is important to emphasize from tourism's perspective that foreigners (spectators and participants together) coming to Budapest due to the WTTC considered the hospitality of the Hungarian people very favourable (an average of 4.61 on a scale of 1-5; SD = 0.64), which was significantly associated with a favourable trend in the willingness to return. $57.1 \%$ of foreigners plan to return to Hungary within 5 years, but among those who rated hospitality as 5 , this proportion was already $62.2 \%$. More than half (55.8\%) of the WTTC's foreign spectators and participants took time to visit one or more sights of the capital.

A higher willingness to spend compared to the general tourists and the general sports tourists was clearly identifiable for both domestic and foreign spectators. This can be explained by the location of the competition, which is the settlement with the highest price level and the widest range of tourist offers in Hungary. The peculiarity of the WTTC is that the most important table tennis manufacturers and distributors in the world came to the event venue with special offers which encourages spectator groups to buy table tennis related goods.

The 2019 WTTC set a record in terms of media. TV channels broadcasted in 145 countries in 1176 hours, reaching 665 million viewers (of which 558 million people were in China, where the number of unique viewers reached almost 150 million). Internet streaming broadcasts were followed over 8 days in 148 countries, for which 4.8 million searches were registered. In the case of social media interfaces viewers watched 34.7 million minutes on the event's YouTube channel, while 27.56 million impressions were registered on Facebook (Péli, 2019).

\section{CONCLUSIONS}

Foreign passive sports tourists coming to the WTTC spent more time at the event and other tourist attractions than foreign general tourists or sports tourists. Average spending of both foreign and domestic passive sports tourists was higher than foreign or domestic general or sports tourists respectively. The full experience package was important for the spectators in addition to the attractiveness of the event, but almost half of the participants also had additional experiences in Hungary beyond the competition.

It can be said that there is a justification of organising world sports events in Hungary for Olympic sports based on the responses of the spectators and participants and their consumer behaviour. Both the Hungarian organisation and hospitality are so high level that the respondents would like to return to the country in the near future, when they will spend again to fuel the Hungarian economy.

The Hungarian government provided almost 4 million euros support to the organisers of the WTTC. Examining the macroeconomic effects of the competition, it can be stated that every EUR of government support increased the country's GDP by 1.21 EUR and generated a tax of 1.01 EUR in 2019. Expenditures of spectators and participants contributed $24 \%$ of the generated GDP, which were not part of the WTTC budget.

Regarding the macroeconomic effects of the WTTC, it can be said that it contributed more than 4.7 million EUR to Hungary's GDP which is more than the subsidy given by the government because of the event. WTTC generated 2.9 million EUR in VAT revenue for the budget and further 1.1 million EUR additional tax revenue for the government's budget. The WTTC's economic impact generated extremely low amount of imports and most of the WTTC related expenditures were spent within the country.

There were also positive sports policy effects in addition to the economic and tourism related effects and Budapest became a focal point in the international media during the competition.

There are also some limitations on the use of inputoutput modelling in the international literature when estimating the complex economic impacts of sports 
competitions (Vörös \& Koppány, 2019). These include supply-side income leakage, one-sided interpretation of demand growth, crowding-out and substitution effects. When quantifying the macroeconomic effects generated by the WTTC some of the mentioned methodological shortcomings do not appear (due to the size of the event) and we tried to handle the constraint related to domestic viewers (substitution effect).

We consider it important to monitor the macroeconomic impact of other world table tennis events in the future, taking into account the local specificities of the host countries, which can contribute to a well-founded tendering process for the organisation of these events. Particular emphasis may also be placed on the ITTF's current efforts to transform adult and youth competition series into a new, even more business-based type.

\section{REFERENCES}

Ács, P. (2007). Bevezetés a sportstatisztikába [Introduction to Sports Statistics]. Budapest-Pécs, Hungary: Dialóg Campus.

Ács, P. (2015). Research Methodology in Sport Sciences. Pécs, Hungary: University of Pécs, Faculty of Health Sciences.

Albers, A. (2004). Sport als Imageträgen im Tourismus: Auswirkungen und Chancen von Sportevents für Destinationen [Sport as image carriers in tourism: Effects and opportunities of sporting events for destinations]. Paderborn, Germany: Verlag des Faches Geographie, Universität Paderborn.

Bánhidi, M. (2015).Sportturisztikai termékek. In:T. Laczkó \& M. Bánhidi (Eds.), Sport és egészségturizmus alapjai [Basics of Sport and Health Tourism]. (pp. 47-75). Pécs, Hungary: University of Pécs, Faculty of Health Sciences.

Bánhidi M. (2018). A nemzetközi sportturizmus területén végzett kutatások elemzése sporttudományi megközelítésben [International sport tourism literature analysis from sport science perspectives]. In T. Szabó, M. Bánhidi \& G. Szőts (Eds.), A sportturizmus gazdasági és társadalmi kérdései Magyarországon (pp. 9-36). Budapest, Hungary: Hungarian Society of Sport Science.

Borbély A., \& Müller A. (2015). Sport és turizmus [Sport and Tourism]. Debrecen, Hungary: Campus.

Chen, N., \& Funk, D.C. (2010). Exploring destination image, experience and revisit intention: a comparison of sport and non-sport tourist perceptions. Journal of Sport Tourism, 15(3), 239-259. https://doi.org/10.108 $0 / 14775085.2010 .513148$

Dreyer, A. (2002). Sport und Tourismus. Wirtschaftliche, soziologische und gesundheitliche Aspekte des Sport-Tourismus [Sport and tourism. Economic, sociological and health aspects of sports tourism]. Wiesbaden, Germany: Universitatsverlag.

European Commission (Eds) (2012). Study on the Contribution of Sport to Economic Growth and Employment in the EU. Retrieved from https:// ec.europa.eu/assets/eac/sport/library/studies/ study-contribution-spors-economic-growth-finalrpt.pdf

European Commission (2018). Eurobarometer - Sport and Physical Activity. Brussels, Belgium. Retrieved from http://ec.europa.eu/commfrontoffice/ publicopinion/index.cfm/survey/getsurveydetail/ instruments/special/surveyky/2164

Hungarian Central Statistical Office (2020). Information database, Main Indicators of foreign tourists in Hungary [Data Set]. http://statinfo.ksh.hu/ Statinfo/themeSelector.jsp? page $=2 \&$ szst $=$ OGT

Hungarian Central Statistical Office (2020). Information database, Characteristics of multi-day domestic trips [Data Set]. http://statinfo.ksh.hu/Statinfo/ themeSelector.jsp?page $=2 \&$ szst=0GT

Hungarian Tourist Agency (2017). Magyar Turizmusfejlesztési Stratégia 2030 [Hungarian Tourism Development Strategy]. Budapest: Hungarian Tourist Agency.

Kóródi, M. (2011). Turizmus kutatások módszertana [Methodology of Tourism Research]. Pécs, Hungary: University of Pécs.

Kovács, A., Paár, D., Elbert, G., Welker, Zs., Stocker, M., \& Ács, P. (2015). A magyar háztartások sportfogyasztási szokásainak felmérése [Survey of Sports Consumption Habits of Hungarian Households]. Pécs, Hungary: University of Pécs, Faculty of Health Sciences.

KPMG (2015). Futóturizmus Budapesten. A Budapest Futóiroda 2015 öszi budapesti futóversenyeinek nemzetgazdasági hatásvizsgálata [Running Tourism in Budapest. National Economic Impact Assessment of the Budapest Running Office's Running Competitions in Budapest in the Autumn 2015]. Retrieved from http:/ / www.futanet.hu/kepo/ PR/gazdasagi_sajttaj/KPMG_BSI_2015-Gazdasagi_ hatastanulm\%C3\%A1ny_Vezetoi_osszefoglalo.pdf

Kundi, V. (2012). Fesztiválok városokra gyakorolt gazdasági- és társadalmi-kulturális hatásainak elemzése. A Győri Magyar Táncfesztivál és a Miskolci Operafesztivál példáján keresztül [Analysis of the Economic and Socio-cultural Impacts of Festivals on Cities. The Example of Hungarian Dance Festival in Győr and Miskolc Opera Festival]. [Doctoral dissertation, Széchenyi István University]. Retrieved from https://rgdi.sze.hu/images/RGDI/ honlapelemei/fokozatszerzesi_anyagok/kundi_ viktoria_vegleges_disszertacio.pdf 
Laczkó, T., \& Paár, D. (2018). Társadalmi hatások vizsgálata a 2018. évi hazai rendezésü nemzetközi sportesemények kapcsán [Research of social effects of domestic organised sport events in 201]. In T. Szabó, M. Bánhidi, \& G. Szőts (Eds.), A sportturizmus gazdasági és társadalmi kérdései Magyarországon (pp. 77-102). Budapest, Hungary: Hungarian Society of Sport Science.

Laczkó, T., \& Stocker, M. (2018). 2018. évi hazai rendezésü nemzetközi sportesemények gazdasági és turisztikai hatásainak vizsgálata [Analysis of socio-economic and tourism impacts of domestic organized sport events in 2018]. In T. Szabó, M. Bánhidi, \& G. Szőts (Eds.), A sportturizmus gazdasági és társadalmi kérdései Magyarországon (pp. 37-76). Budapest, Hungary: Hungarian Society of Sport Science.

Laczkó, T., \& Stocker, M.(2020). A2017.évi hazai rendezésű nemzetközi sporteseményekre érkező külföldi turisták fogyasztásának nemzetgazdasági hatásai [The economic impact of consumption by foreign visitors to major international sporting events in Hungary in 2017]. Turizmus Bulletin, 20(2), 22-33. https://doi.org/10.14267/TURBULL.2020v20n2.3

Laflin, M. (2018). The Explosion of International Sport Events. Retrieved from https://drive.google.com/ file/d/1GbwBRjfV9kB5Y6cbfi2v2PYebDe7a5Lc/view

Lasztovicza, D., \& Béki, P. (2016). A sport és a turizmus kapcsolata, a sportturizmus fogalmi rendszere [The Connection between Sport and Tourism, the Conceptual System of Sport Tourism]. Testnevelés, Sport, Tudomány, 1(1), 39-50. https://doi. org/10.21846/TST.2016.1.4

Paár, D., \& Laczkó, T. (2018). 2018. évi hazai rendezésű nemzetközi sportesemények sportszakmai, sportpolitikai és sporttechnológiai hatásainak vizsgálata [Research of domestic organised sport events' effects from the point of view sport performance, sport politics and sport technology in 2018]. In T. Szabó, M. Bánhidi, \& G. Szőts (Eds.), A sportturizmus gazdasági és társadalmi kérdései Magyarországon (pp. 103-130). Budapest, Hungary: Hungarian Society of Sport Science.

Péli, L. (2019). Asztalitenisz-vb tévés és host broadcast tapasztalatok [TV and Host Broadcast Experiences of World Table Tennis Championship]. Retrieved from https://pelicom.hu/portfolio/asztaliteniszvb-teves-es-host-broadcast-tapasztalatok/

Schwark, J. (2005). Wirtschaftliche Bedeutung des 3. KarstadtRuhrMarathons 2005. Bocholt, Germany: FH Gelsenkirchen http://www.sport-tourismus.de/ pdf/2005_karstadt_ruhr_marathon_zuschauer.pdf

Sportcal Global Communications Ltd. (2017). GSI Event Study / FIS Nordic World Ski Championships 2017. Retrieved from https://www.sportcal.com/ Reports/Search/44
Sportcal Global Communications Ltd. (2018). The World Games 2017. Retrieved from https://www.sportcal. com/Impact/EventStudies

Sportcal Global Communications Ltd. (2019a). Global Sports Impact Report 2019. Retrieved from https:/ / drive.google.com/file/d/1xp768UG8LsouOvI0N7EPL ixR6Skj03s5/view

Sportcal Global Communications Ltd. (2019b). IFF Men's World Floorball Championships 2018. Retrieved from http://dltaw1vhj9zy5.cloudfront.net/2019/05/ Sportcal-GSI-Event-Study-IFF-Mens-WorldChampionships-2018-FINAL-Public-version.pdf

Standeven, J., \& De Knop, P. (1999). Sport tourism. Leeds, United Kingdom: Human Kinetics Europe.

Stocker, M. (2013). Dematerializálódás szerepe az értékteremtésben [Demate value creation]. Vezetéstudomány, 14(12), 44-53.

Stocker, M. \& Boda, Gy. (2018). A sportszektor gazdaságdinamizáló hatása [The Economic Dynamising Effect of Sports Sector]. Magyar Sporttudományi Szemle, 19(75), 78.

Stocker, M., \& Laczkó, T. (2020). Expenditures of CEE and Non-CEE spectators in major international sport events in Hungary. Problemy zarzadzania - Management issues, 2020(87):81-98. DOI: 10.7172/1644-9584.87.4

Stocker, M. \& Szabó, T. (2017). A hazai sportirányítás szerepe és tevékenysége a kiemelt hazai sportesemények esetében [Role and activity of Hungarian national sport governance in international sport events]. In M. Szmodis, G. Szőts (Eds.), A sportirányítás gazdasági kérdései - 2017, Magyar Sporttudományi Füzetek XVI. (pp. 56-77). Budapest, Hungary: Hungarian Society of Sport Science.

Sulyok, J., \& Magyar, Zs. (2014). Az aktív turizmus helyzete Magyarországon. Fókuszban a kerékpározás és a természetjárás [The Situation of Active Tourism in Hungary. Cycling and Hiking in Focus]. Turizmus Bulletin, 16(3-4), 15-26.

Vörös, T., \& Koppány, K. (2019). Sportlétesítményberuházások társadalmi-gazdasági hatásainak értékelési lehetőségei [Methodological approaches to assess social and economic impacts of sport facility investments]. In T. Gyömörei (Ed.), Egészség, Sport, Gazdaság (pp. 18-31). Győr, Hungary: Széchenyi István University of Győr. 